буде підірвана, що призведе до недовіри та підозри щодо будь-якої зеленої реклами [3, с. 52].

Важливо зазначити, що за таких умов, держава не має залишатися осторонь цих процесів. Потребують правової регламентації заходи 3 протидії неетичним маркетинговим технологіям (як «грінвошинг» тощо). 3 іншого боку, актуальним є вироблення правових інструментів щодо стимулювання та заохочення добросовісних представників бізнесу, які впроваджують ефективні соціально-відповідальні практики у своїй діяльності. Особливу увагу слід приділяти заходам, що спрямовуються на підвищення рівня обізнаності суспільства щодо «грінвошингу», на формування та розвиток екологічно орієнтованої системи цінностей серед споживачів та підприємців. Тому збалансування державного регулювання та ринкової саморегуляції має стати детермінантою формування правової моделі сталого розвитку держави.

\title{
Література:
}

1. Клименко I. М. Корпоративна соціальна відповідальність в контексті цілей сталого розвитку. Державне управління: удосконалення та розвиток. 2018. № 8. URL: http://www.dy.nayka.com.ua/?op=1\&z=1292

2. Клименко I. М. Моделі державного регулювання корпоративної соціальної відповідальності. Вісник НАДУ. Серія "Державне управління». 2019. № 4 (95). С. 105-112.

3. Грищенко О.Ф., Голишева С.О. Використання грінвошингу як технології екологізації бізнесу: поняття, детермінанти та драйвери. Науковий вісник Міжнародного гуманітарного університету. 2020. № 46. C.47-54.

DOI https://doi.org/10.30525/978-9934-26-074-2-22

\section{ВИДИ ДЕРЖАВНОЇ ДОПОМОГИ СУБ'СКТАМ ГОСПОДАРЮВАННЯ В УМОВАХ COVID-19}

\author{
Феофанова I. М. \\ аспірантка кафедри господарського права і процесу \\ Національного університету «Одеська юридична академія» \\ м. Одеса, Україна
}

На сьогоднішній день сфера господарювання переживає дуже важкий період, який пов'язаний із світовою пандемією - COVID-19. Чисельні вітчизняні суб'єкти господарювання повністю або частково припиняють 
свою діяльність через обмеження, які вводить держава. У такий час дуже важливим є своєчасна адекватна реальна допомога зі сторони держави, на підставах та умовах визначених чинним законодавством. Сумно констатувати, але «за даними «Global Innovation Index 2019» упродовж останніх років Україна перебуває у списку країн з доходом на душу населення нижче середнього і станом на 2019 рік займає друге місце серед 26 країн, що увійшли до вибірки за цим критерієм (зі 130 країн світу, охоплених дослідженням)» [1, с. 64]). Адже як зазначають експерти Міжнародного валютного фонду, у найвищій зоні ризику під час нинішньої кризи опиняться саме країни з низьким рівнем доходів на душу населення, та країни, що розвиваються [2].

Особливо такої допомоги з боку держави потребують суб'єкти малого підприємництва, адже саме «підтримка та допомога суб'єктам малого підприємництва повинна бути обов'язковою умовою економічної та політичної стабілізації в країні. Мале підприємництво $є$ основою економіки країни, воно сприяє зростанню матеріального потенціалу суспільства, створює нові умови для працевлаштування людей та здійснює різноманітні таланти громадян. Активна підтримка розвитку суб’єктів малого підприємництва сприяє зростанню ВВП та створенню нових робочих місць» [3, с. 14].

При проведенні опитування представників малого бізнесу, останні до першочергових заходів, які мають бути вжиті органами державної влади для полегшення економічних наслідків впливу COVID-19 на бізнес називають: захист і підтримка національних виробників; імпортозаміщення з метою розвитку власного виробництва та постачання сировини; фінансова підтримка підприємств для виходу з кризи після закінчення карантину; стимулювання створення робочих місць з метою збереження робочої сили в Україні; підтримка стратегічних проектів щодо енергетики та телекомунікацій, фінансова підтримка працівників підприємства, які залишились без роботи; виплати по частковому безробіттю, щоб не звільняти працівників; безумовна підтримка всього населення на прикладі Німеччини та США; відновлення роботи міського та приміського транспорту; відновлення роботи будівельного комплексу; розміщення державного замовлення для промисловості; реформування трудового законодавства; дозвіл на роботу торгівельних магазинів, закладів з розміщення, які можуть забезпечити всі заходи із запобігання розповсюдженню COVID-19, що дасть можливість розпочати роботу підприємств; мораторій на підвищення цін монополістами на відповідних ринках [4]. Потрібна саме «ефективна і системна протидія епідемії є можливою лише у разі злагодженої співпраці усіх державних інститутів, та направленість держави на подолання наслідків пандемії 
з усіма суб'єктами господарювання, інтенсифікації державно-приватного партнерства, посилення цифровізації послуг, розвитку соціально орієнтованого бізнесу, та орієнтованість держави на підтримку постраждалого бізнесу від наслідків пандемії» [5, с. 170].

На думку В.В. Сичової «види державної підтримки суб'єктів малого підприємництва в умовах пандемії різняться за сферою їх застосування, $\mathrm{i}$ в основному така підтримка має фінансовий характер. Разом із цим важливе місце у підтримці вітчизняних малих підприємств мають посісти й заходи, які мають організаційний характер, серед яких варто назвати: проведення консультацій з маркетингових питань, планування та організації власної справи, питань кредитування та оподаткування; проведення консультацій з приводу правового забезпечення підприємницької діяльності в Україні; організація конференцій, форумів на онлайн платформах, насамперед для малого і середнього підприємництва; надання допомоги у лобіюванні інтересів національних товаровиробників стосовно експорту вітчизняних товарів; організація дистанційних семінарі та бізнес-тренінгів; тощо» [6, с. 156]. Тобто, мова йдеться про пріоритет організаційно-правових заходів, які держава може й повинна надавати як види державної допомоги, задля чого потрібно відповідне сучасне інформаційно-цифрове забезпечення державних органів.

В останній час держава прийняла ряд нормативно-правових актів, здебільшого підзаконного та відомчого характеру, які містять окремі види державної допомоги щодо оподаткування діяльності суб'єктів господарювання (звільнення від сплати єдиного соціального внеску для фізичних осіб-підприємців; обмеження застосування більшості штрафів за порушення податкового законодавства; мораторій на проведення документальних та фактичних перевірок (виключення - перевірки щодо відшкодування ПДВ); дозвіл фізичним особам-підприємцям тимчасово не заповнювати книгу обліку доходів, тощо); фінансово-розрахункових відносин (кредитні канікули; капіталізація відсоткових платежів). Майже рік назад був поданий законопроект [7], який вкрай важливо прийняти та, який вже повинен практично працювати. Міністерство економіки звітує, що «455 тисяч осіб отримали по 8 тисяч гривень матеріальної допомоги від держави за карантин. До пів мільйона людей отримали від держави одноразову матеріальну допомогу в розмірі 8 тисяч гривень. Загалом перераховано 3,64 мільярда гривень» [8]. На нашу думки це одноразові «акції» держави, які запроваджуються, як правило, несвоєчасно та одноразово. Потрібно прийняти програмний документ, який містив би умови та порядок систематичних різноманітних видів державної допомоги на засадах планування, як короткотак і довгострокового, адже, дуже мало підстав стверджувати про те, що 
карантинні дні швидко минуть. Таких умов господарювання, які були 2-3 роки назад вже не буде, а будуть обмеження та заборони.

Таким чином, види державної допомоги суб'єктам господарювання в умовах COVID-19 це сукупність своєчасних, адекватних, реальних, безповоротних та першочергових заходів організаційного, фінансового, податкового, соціального характеру, направлених на їх підтримку та/або відновлення за рахунок державного бюджету. Класифікувати види державної допомоги можливо за наступними критеріями в залежності від: 1) характеру - фінансові та нефінансові (організаційні, інформаційно-консультаційні, тощо); 2) строку - короткострокові, середньострокові та довгострокові; 3) суб'єктного складу - ті, які надаються мікропідприємцям, малим підприємцям та середнім підприємцям.

\section{Література:}

1. The global innovation index 2019. Cornell University, INSEAD, WIPO. 2019. 78 p. URL: https://www.wipo.int/edocs/pubdocs/en/

2. Сайт Міжнародного валютного фонду. URL: https://www.imf.org/ en/News/Articles/2020/04/07/sp040920-SMs2020-Curtain-Raiser

3. Кміть В.М., Падура А.В. Державна підтримка суб'єктів малого підприємництва. Науковий вісник Ужгородського національного університету. Серія: Право. 2016. Вип. 7, ч. 2. С. 14-17.

4. Бізнес та COVID-19: вижити не можна померти. Федерація роботодавців України: сайт. URL: https://fru.ua/images/doc/analitics/

5. Стріжкова А.В., Забашта М.В. Державна підтримка суб'єктів господарювання в умовах пандемії COVID-19. Цифрові трансформації України 2020: виклики та реалії: зб. наук. пр. НДІ ПЗІР НАПрН України № 1 за матеріалами круглого столу, 18 вересня 2020 р. Харків: НДІ ПЗІР НАПрН України, 2020. С. 164-173.

6. Сичова В.В. Види державної підтримки суб'єктів малого підприємництва в умовах пандемії. Актуальні питання діяльності суб'єктів господарювання в умовах пандемії COVID-19: матеріали міжнар. наук.-практ. конф. (м. Харків, 26 лют. 2021 р.). МВС України, Харків. нац. ун-т внутр. справ. Харків: ХНУВС, 2021. С. 153-157.

7. Про внесення змін до деяких законодавчих актів, спрямованих на забезпечення додаткових соціальних та економічних гарантій у зв'язку з поширенням коронавірусної хвороби (COVID-2019): Проект Закону України від 29.03.2020 p. Інформаційний ресурс. Режим доступу: https:zakon.rada.gov.ua/

8. Влада України звітує: майже пів мільйона осіб отримали допомогу у 8 тисяч гривень. Інформаційний ресурс. Режим доступу: https://www.dw.com/uk 